\title{
Physicochemical Characteristics of Malaysian Stingless Bee Honey from Trigona Species
}

\author{
Fatima $\mid \mathrm{J}^{1}$, Mohd Hilmi $A \mathrm{~B}^{1}$, Salwani $\mathrm{I}^{2}$, Lavaniya $\mathrm{M}^{3}$ \\ ${ }^{1}$ Faculty of Health Sciences, Universiti Sultan Zainal Abidin, Gong Badak Campus, 21300 Kuala Nerus, \\ Terengganu, Malaysia ${ }^{2}$ Faculty of Medicine, Universiti Sultan Zainal Abidin, Medical Campus, 20400 Kuala \\ Terengganu, Terengganu, Malaysia ${ }^{3}$ Department of Pharmacology, Universiti Sains Malaysia, 16130 Kubang \\ Kerian, Kelantan, Malaysia.
}

\begin{abstract}
The physicochemical properties of stingless bee honey are diverse according to origin of geographical or botanical and fruit or flower season. These factors result in production of honey with different colour, $\mathrm{pH}$, ash and water content although the bee species is similar. To date, the physicochemical properties of honey from Malaysian Trigona species are unknown. Therefore, determination of physicochemical properties of honey from stingless bee is crucial for Malaysian researchers in order to analyse the purity of the honey. Five honey samples were used for the current study. Four samples were stingless bee honey from two of the most common domesticated Malaysian stingless bee species; Trigona thorasica and Trigona itama. Meanwhile, one sample was from Tualang honey. For stingless bee honey, the values for $\mathrm{pH}$, moisture content, electrical conductivity, ash content and hydroxymethylfurfural (HMF) were $2.79 \pm 0.04$ to $2.95 \pm 0.02,28.3 \pm 0.68$ to $33.7 \pm 0.51,0.47 \pm 0.22$ to $0.55 \pm 0.38,0.132 \pm 0.03$ to $0.532 \pm 0.83$ and $0.080 \pm 0.16$ to $3.42 \pm 1.03$, respectively. The colour of stingless bee honey varies based on observation or absorbance assay. The study described the physicochemical properties derived from Malaysian bees of Trigona thorasica, Trigona itama, and Apis Dorsata.
\end{abstract}

KEYWORDS: Malaysian Stingless Bee; Physicochemical properties

\section{INTRODUCTION}

Stingless bee honey is a desirable bee product, which has been consumed for ages in its natural form. ${ }^{1,2}$ It has been practiced traditionally in the Malay, Arab, Hebrew, Persian, Indian, Roman and Chinese communities. Previously, it is referred as pot-honey, a legacy of stingless bee. However, the Malay addresses it as "madu kelulut". This stingless bee honey is composed of carbohydrates, amino acids, phenolic compounds, organic acids, vitamins, minerals, lipids and enzymes. These forms the major constituents of the honey. ${ }^{3}$ The honey of stingless bee and Apis are similar in their compositional property such as ash and nitrogen content. ${ }^{4}$ However, they are different in term of moisture content, acidity, viscosity, and sucrose and mineral composition. ., $^{5}$ The stingless bees forage on broadspectrum of flowers that grow at different types of habitat, hence they produce different honey composition. Most of the physicochemical properties of honey mainly depend on the botanical source of the nectar, the environmental and climatic conditions as well as the species of the stingless bee that produce the honey. Before the introduction of sugarcane and Apis honey, stingless bee honey was the first and foremost source of sweetener. ${ }^{7,8}$ It has

Mohd Hilmi $\mathrm{AB}$

Faculty of Health Sciences, Universiti Sultan Zainal Abidin, Gong Badak Campus, 21300 Kuala Nerus, Terengganu, Malaysia

Email: mhilmiab@unisza.edu.my been utilized as food, sweetener or for production of traditional fermented drink such as balche. The Mayan civilization has used this drink for its ritual activity. ${ }^{8,9}$

The native stingless bees found in Malaysia are primarily known for their great ecological significance as plant pollinators. ${ }^{10}$ Products of the Malaysian stingless bee such as honey and propolis are of significant nutritional and therapeutic value. ${ }^{11}$ The utilization of stingless bee honey as a traditional natural remedy has been in practice for the past few decades among Malay people. Currently, demands on stingless bee products including honey, propolis and hive are increasing. In addition, interest on farming the stingless bee is increasing among people in the rural residence especially in Kelantan, Terengganu, Perak and Kedah to suffice the high demand on crude honey and honey-based products.

Honey as a medicine has been mentioned by Allah Almighty in the Quran; (Chapter 16, sentence 69) "There comes from their bellies a drink of many colours in which there is healing for mankind. Abu Hurairah said "Whoever eats honey three times a month will not fit with any great disaster. Aisha said "The Prophet of Allah did indeed love to eat sweetmeats and honey". The prophet of Allah used to drink a cup of water and honey on an empty stomach every day. This is a tremendously prudent thing to do to preserve everyone's health. Health treatment using honey absolutely has long been 
practiced among Muslim community since more than one thousand years ago.

Determination of the physicochemical properties of stingless bee honey from Trigona thorasica and Trigona itama which are the most commonly available and utilized in Malaysia is very crucial. Ultimately, the finding is beneficial for setting the quality of food standard and honey characterization especially in the identification of Malaysian stingless bee honey. Therefore, the purity of honey can be determined and artificial or adulterated honey may be easily identified. ${ }^{12}$ To date, this type of finding is unknown although many research on stingless bee have been done in our country. The main purpose for this study was to investigate the physicochemical characteristics of Malaysian stingless bee honey.

\section{MATERIALS AND METHODS \\ Honey Bee}

Five fresh honey samples were collected directly from the bee farms. Information of honey samples were shown in Table 1.

Table 1: The identification of honey samples

\begin{tabular}{ccclc}
\hline Honey code & Bee species & Farm location & Main nectar & Time of collection \\
\hline Honey A & Trigona thorasica & Kelantan & Monofloral & Durian season \\
Honey B & Trigona itama & Kelantan & Monofloral & Durian season \\
Honey C & Trigona thorasica & Terengganu & Multifloral & Normal season \\
Honey D & Trigona itama & Terengganu & Multifloral & Normal season \\
Honey E & Apis dorsata & Terengganu & Multifloral & Normal season \\
\hline
\end{tabular}

$\mathrm{pH}$

The $\mathrm{pH}$ was determined by following the method of Belay et al. (2013) which was adapted from the AOAC, 1990 method number 962.19. Gently $10 \mathrm{~g}$ of each of the honey sample were separately measured in clean beakers and labeled accordingly. Each of the labeled sample was well mixed with 75 $\mathrm{mL}$ of sterile distilled water until a homogenous solution was achieved. After calibrating the $\mathrm{pH}$ meter with a standard buffer solution with $\mathrm{pH}$ of 4 , 7 and 10, the glass electrode was gently immersed into the honey solution. Readings were recorded, and the procedure was repeated three times in order to achieve accurate result. ${ }^{13}$

\section{Ash Content}

The ash content was determined using the adopted method of Chuttong et al. (2016) from the AOAC 2006 number 962.19. Clean crucibles were oven dried at $105{ }^{\circ} \mathrm{C}$ for six hours. The crucibles were then transferred to desiccators with a porcelain plate and desiccant. The desiccators were then covered and the crucibles were allowed to cool before being weighed. The empty dried crucibles were then labeled, weighed and recorded accordingly. Five grams of each of the honey samples was weighted into the respective labeled crucible and carefully placed in a muffle furnace at $550{ }^{\circ} \mathrm{C}$ for 12 hours. After cooling, the crucibles were weighed and recorded accordingly. The ash content was calculated as follows:

Ash content $(\mathrm{g})=$ Weight after ashing - Tare weight of crucible $\times 100$ Original sample weight

\section{Moisture Content}

The moisture content was determined using a digital Atago handheld refractometer (Kruss, HRH30). A few drops of honey was gently placed in the sample plate and then covered. Displayed readings were recorded and the procedure was repeated three times. The moisture content was calculated as 100 Brix $=$ moisture content $(0$ to $85 \%$ Brix range with an accuracy of $\pm 0.2 \%) .{ }^{14}$

\section{Electrical Conductivity}

Electrical conductivity (EC) was measured using a conductivity meter HI 98311 (Hanna Instruments). A $20 \%(\mathrm{w} / \mathrm{v})$ solution of honey was prepared by weighing $2 \mathrm{~g}$ of honey to $10 \mathrm{~mL}$ distilled water. After calibrating the EC meter, the conductance cell was suspended into the honey solution and the readings were recorded (Chuttong et al., 2016). The procedure was repeated for each sample three times.

\section{Colour Intensity}

Using the method of Pontis et al. (2014), $5 \mathrm{~g}$ of each of the honey sample was dissolved in $10 \mathrm{ml}$ demonized water and gently mixed with a vortex mixer. About $2 \mathrm{ml}$ of the solution was transferred in to curvets and the absorbance was measured using a spectrophotometer at $635 \mathrm{~nm}$. The recorded absorbance was matched with the Pfund scale. ${ }^{15}$

\section{Hydroxymethylfurfural}

Gas chromatography mass spectrometry was used to identify the hydroxymethylfurfural. The samples 
were send to Universiti Malaysia Pahang.

\section{RESULTS}

The $\mathrm{pH}$ values of the stingless bee honey $\mathrm{A}, \mathrm{B}, \mathrm{C}$ and $D$ ranged between $2.79 \pm 04$ to $2.95 \pm 0.02$, while the $\mathrm{pH}$ of honey $\mathrm{E}$ was $3.64 \pm 0.04$. All of the honey types are characterized as acidic. The results showed that although with different geographical and botanical source of the honey samples, their $\mathrm{pH}$ were almost within the same range. The finding may suggest that stingless bee honey has similar range of $\mathrm{pH}$ regardless their origin. The ash content value obtained for all stingless bee honey ranged between $0.132 \mathrm{~g} / 100 \mathrm{~g}$ to $0.532 \mathrm{~g} / 100 \mathrm{~g}$, while the ash content of Tualang honey was $0.668 \mathrm{~g}$. The highest moisture content of $33.7 \%$ was determined from honey $A$ and the lowest of $28.3 \%$ from honey D. Meanwhile, the moisture content for honey $\mathrm{E}$ was $24.8 \%$. The high moisture content of stingless bee honey is important and differs from the Apis honey. Dissimilar to the stingless bee honey, Apis honey contains very less water and this results in its high viscosity. The electrical conductivity (EC) results ranges from $0.47 \mathrm{mS} / \mathrm{cm}$ to $0.55 \mathrm{mS} / \mathrm{cm}$ for stingless bee honey and $0.23 \mathrm{mS} / \mathrm{cm}$ for Tualang honey. The results for color analyses of each honey were categorized based on the absorbance measurement. The absorbance of honey A was 0.457 and categorized as extra light amber. Honey B was 1.056 and honey $D$ was 0.694 both of which were categorized as light amber. Honey C was 0.239 , and honey $\mathrm{E}$ was 0.385 and were both categorized as white. After absorbance measurement, both were characterized as being in similar category as expected. In contrast, honey $\mathrm{C}$ and honey $\mathrm{E}$, by direct observation indicates the yellow to golden color and darker than golden color respectively. Meanwhile, after absorbance measurement, both of them were identified as white color. Therefore, absorbance measurement is very crucial rather than completely depends on direct observation. All color of the honey samples were in accordance to the Pfund scale.

Low hydroxymethylfurfural (HMF) values were determined from three honey samples. The lowest HMF was determined in honey $B(0.80 \mathrm{mg} / \mathrm{kg})$ and the highest in honey $D(3.42 \mathrm{mg} / \mathrm{kg})$. Meanwhile, HMF value for Tualang honey is $0.75 \mathrm{mg} / \mathrm{kg}$. The detailed psychochemical properties of stingless bee honey and Tualang honey are recorded on Table 2.

Table 2: The psychochemical properties of Malaysian Trigona and Apis honey $(n=3)$.

\begin{tabular}{ccccccc}
\hline $\begin{array}{c}\text { Honey } \\
\text { code }\end{array}$ & $p H$ & $\begin{array}{c}\text { Moisture } \\
\text { Content } \\
(\%)\end{array}$ & $\begin{array}{c}\text { Colour } \\
\text { (Abs) }\end{array}$ & $\begin{array}{c}\text { Electric } \\
\text { conductivity } \\
(\mathrm{mS} / \mathrm{cm})\end{array}$ & $\begin{array}{c}\text { ASH } \\
\text { Content } \\
(\mathrm{g} / 100 \mathrm{~g})\end{array}$ & $\begin{array}{c}\mathrm{HMF} \\
(\mathrm{mg} / \mathrm{kg})\end{array}$ \\
\hline Honey A & $2.79 \pm 0.04$ & 33.7 & $0.457 \pm 0.64$ & $0.47 \pm 0.22$ & $0.132 \pm 0.03$ & $2.56 \pm 0.96$ \\
Honey B & $2.93 \pm 0.03$ & 31.7 & $1.056 \pm 0.30$ & $0.55 \pm 0.06$ & $0.268 \pm 0.21$ & $0.080 \pm 0.16$ \\
Honey C & $2.95 \pm 0.02$ & 28.9 & $0.239 \pm 0.09$ & $0.53 \pm 0.10$ & $0.4 \pm 0.03$ & $0.92 \pm 0.17$ \\
Honey D & $2.92 \pm 0.01$ & 28.3 & $0.694 \pm 0.88$ & $0.55 \pm 0.38$ & $0.532 \pm 0.83$ & $3.42 \pm 1.03$ \\
Honey E & $3.64 \pm 0.04$ & 24.8 & $0.385 \pm 0.61$ & $0.23 \pm 0.33$ & $0.668 \pm 0.28$ & $0.75 \pm 0.44$ \\
\hline
\end{tabular}

\section{DISCUSSION}

The common pH for Malaysian stingless bee honey is undetermined. The $\mathrm{pH}$ values obtained from the current study were almost similar with the findings of Silva et al. that ranges between $2.90 \pm 0.0$ to $3.83 \pm 0.1$. They analyzed using nine Brazilian Jandaira honey (Melipona subnitida). ${ }^{17}$ Moreover, similar results were also shown in previous study that utilized 152 stingless bee honeys. ${ }^{18}$ However, recent studies on stingless bee honey have indicated the mild $\mathrm{pH}$ range of $4.1 \pm 0.0$ to $4.5 \pm 0.0$ for Colombian stingless bee honey ${ }^{19}$ and $3.06 \pm 0.12$ to $5.18 \pm 1.35$ for Guatemalan stingless bee honey. ${ }^{20}$ Low $\mathrm{pH}$ value usually indicates more acidity and more hydrogen ion, that involved in the formation of other compounds in stingless bee honey. ${ }^{21}$ The lower the $\mathrm{pH}$ of the honey, the higher ability of the honey to inhibit the presence and growth of microorganisms. ${ }^{17}$
All the ash content obtained from the stingless bee honey were aligned within the suggested standards (max $0.5 \mathrm{~g} / 100 \mathrm{~g})$ for Melipona favosa honey from Venezuela. The values were almost similar with the previous study, $0.03 \mathrm{~g} / 100 \mathrm{~g}$ to $0.40 \mathrm{~g} / 100 \mathrm{~g}^{22}$ and with study conducted in Brazil, $0.52 \mathrm{~g} / 100 \mathrm{~g}$ to 0.03 $\mathrm{g} / 100 \mathrm{~g} .{ }^{23}$

The water content of stingless bee honey depends on various factors such as fruit or flower season, the geography that affect the temperature, bee species and maturity of the honey. The moisture content of our stingless bee honey was almost similar to the findings of Nascimento and coworkers. Their research team have used the Brazilian honey and obtained the moisture content ranging between $25.99 \%$ to $36.99 \% .{ }^{24}$ Some stingless bee honey indicated a mild water content as shown in previous studies, $23.40 \%$ to $25.60 \%{ }^{25}$, 
$23.70 \%{ }^{26}$ and $22.7 \%$ to $35.4 \%$.

The EC result ranges from $0.47 \mathrm{mS} / \mathrm{cm}$ to 0.55 $\mathrm{mS} / \mathrm{cm}$ for stingless bee honey and $0.23 \mathrm{mS} / \mathrm{cm}$ for Tualang honey. The EC values are almost similar with the study from Thailand, $0.53 \mathrm{mS} / \mathrm{cm}$ to 0.71 $\mathrm{mS} / \mathrm{cm} .{ }^{28}$ However, our EC are lower than the previous findings which reported $1.1 \mathrm{mS} / \mathrm{cm}^{29,30}$ The EC of honey $E$ was in the range of $0.26 \mathrm{mS} / \mathrm{cm}$ as previously reported for the Apis honey. ${ }^{31}$ The EC is an important criteria for determination of floral origin and also to regulate the concentration of organic acids, minerals, and proteins. ${ }^{2,32}$

Similar to other physicochemical parameters, the color of honey is affected by mineral content and also geographical and botanical origin. Diverse condition may produce different honey color either white, colorless, pale yellow, golden or amber. ${ }^{33}$ Storage duration and light exposure are affecting the color of honey. ${ }^{23}$ Previous study has characterized that darker honey has higher mineral content than the light honey. ${ }^{34,35}$

The HMF specifies the freshness of the honey and may present in a small proportion. Initially, the formation of HMF is due to poor handling, storage or processing, honey degradation and also prolonged exposure of high temperature or hitting. Ultimately, fructose in the honey is decomposing and reacting with acid. ${ }^{36,37,38}$ For stingless bee honey, maximum HMF suggested by previous study is $40 \mathrm{mg} / \mathrm{kg} .{ }^{39}$ Souza and co-workers obtained HMF value ranging from $2.4 \mathrm{mg} / \mathrm{kg}$ to $16.0 \mathrm{mg} / \mathrm{kg}$ for stingless bee honey. ${ }^{18}$ Meanwhile, HMF values below than $2.4 \mathrm{mg} / \mathrm{kg}$ were obtained from Guatemalan stingless bees honey. ${ }^{20}$

\section{CONCLUSION}

Our study revealed for the first time the range of physicochemical characteristics of Malaysian stingless bee honey from the Trigona species. Our finding was comparable with the other groups in term of $\mathrm{pH}$, ash content, moisture content, electrical conductivity, color intensity and hydroxymethylfurfural content. Higher moisture content and $\mathrm{pH}$ are the principal characteristics of the stingless bee honey compared to the Apis Dorsata honey.

\section{ACKNOWLEDGEMENTS}

The authors thank Universiti Sultan Zainal Abidin for awarding Dana Penyelidikan Universiti

(UniSZA/2015/DPU/8) and Research Management, Innovation \& Commercialization Centre (RMIC) for supporting the writing of this article.

\section{REFERENCES}

1. Crane EE. The World History of Beekeeping and Honey Hunting: Routledge, 2013.
2. Karabagias IK, Badeka AV, Kontakos S, et al.,. Botanical Discrimination of Greek Unifloral Honeys with Physico-Chemical and Chemometric Analyses. Food chemistry 2014; 165: 181-90.

3. Manzanares AB, García ZH, Galdón BR, et al.,. Physicochemical Characteristics of Minor Monofloral Honeys from Tenerife, Spain. LWTFood Science and Technology 2014; 55 : 572-8.

4. Alvarez-Suarez JM, Giampieri F, GonzálezParamás AM, et al.,. Phenolics from Monofloral Honeys Protect Human Erythrocyte Membranes against Oxidative Damage. Food and Chemical Toxicology 2012; 50: 1508-16.

5. Kek SP, Chin NL, Tan SW, et al., , Classification of Honey from Its Bee Origin Via Chemical Profiles and Mineral Content. Food Analytical Methods 2016: 1-12.

6. Vit P, Gutiérrez MG, Rodríguez-Malaver AJ, et al.,. Comparación De Mieles Producidas Por La Abeja Yateí (Tetragonisca Fiebrigi) En Argentina Y Paraguay. Acta bioquímica clínica latinoamericana 2009; 43: 219-26.

7. DeMera JH, Angert ER. Comparison of the Antimicrobial Activity of Honey Produced by Tetragonisca Angustula (Meliponinae) and Apis Mellifera from Different Phytogeographic Regions of Costa Rica. Apidologie 2004; 35: 411-7.

8. Jones R. Stingless Bees: A Historical Perspective. Pot-Honey: Springer, 2013;219-

27.

9. Rosales GRO. Medicinal Uses of Melipona Beecheii Honey, by the Ancient Maya. PotHoney: Springer, 2013;229-40.

10. Eltz T, Brühl CA, Imiyabir Z, et al.,. Nesting and Nest Trees of Stingless Bees (Apidae: Meliponini) in Lowland Dipterocarp Forests in Sabah, Malaysia, with Implications for Forest Management. Forest Ecology and Management 2003; 172: 301-13.

11. Zainol MI, Yusoff KM, Yusof MYM. Antibacterial Activity of Selected Malaysian Honey. BMC complementary and alternative medicine 2013; 13: 129.

12. Cantarelli M, Pellerano R, Marchevsky E, et al.,. Quality of Honey from Argentina: Study of Chemical Composittion and Trace Elements. The Journal of Argentine Chemical Society 2008; 96: 33-41.

13. Belay A, Solomon W, Bultossa G, et al.,. Physicochemical Properties of the Harenna Forest Honey, Bale, Ethiopia. Food chemistry 2013; 141: 3386-92.

14. Chuttong B, Chanbang $Y$, Sringarm K, et al.,. Physicochemical Profiles of Stingless Bee (Apidae: Meliponini) Honey from South East Asia (Thailand). Food chemistry 2016; 192: 149 - 55.

15. Pontis JA, Costa LAMAd, Silva SJRd, et al.,. Color, Phenolic and Flavonoid Content, and Antioxidant Activity of Honey from Roraima, 
Brazil. Food Science and Technology (Campinas) 2014; 34: 69-73.

16. Seisonen S, Kivima E, Vene K. Characterisation of the Aroma Profiles of Different Honeys and Corresponding Flowers Using Solid-Phase Microextraction and Gas Chromatography-Mass Spectrometry/Olfactometry. Food chemistry 2015; 169: 34-40.

17. Silva TMS, dos Santos FP, EvangelistaRodrigues A, et al.,. Phenolic Compounds, Melissopalynological, Physicochemical Analysis and Antioxidant Activity of Jandaíra (Melipona Subnitida) Honey. Journal of Food Composition and analysis 2013; 29: 10-8.

18. Souza B, Roubik D, Barth O, et al.,. Composition of Stingless Bee Honey: Setting Quality Standards. INTERCIENCIA-CARACAS2006; 31: 867.

19. Fuenmayor CA, Díaz-Moreno AC, ZuluagaDomínguez CM, et al.,. Honey of Colombian Stingless Bees: Nutritional Characteristics and Physicochemical Quality Indicators. Pot-Honey: Springer 2013;383-94.

20. Dardón MJ, Maldonado-Aguilera C, Enríquez E. The Pot-Honey of Guatemalan Bees. PotHoney: Springer 2013;395-408.

21. de Carvalho CAL, de Almeida Souza B, da Silva Sodré G, et al.,. Mel De Abelhas Sem Ferrão: Contribuição Para a Caracterização FísicoQuímica: Universidade Federal da Bahia/ SEAGRI-BA, 2005.

22. Marinus J. Water Content of Stingless Bee Honeys (Apidae, Meliponini): Interspecific Variation and Comparison with Honey of Apis Mellifera. Apidologie 2006; 37: 480-6.

23. de Sousa JMB, de Souza EL, Marques G, et al.,. Sugar Profile, Physicochemical and Sensory Aspects of Monofloral Honeys Produced by Different Stingless Bee Species in Brazilian Semi-Arid Region. LWT-Food Science and Technology 2016; 65: 645-51.

24. do Nascimento AS, Marchini LC, de Carvalho CAL, et al.,. Determining the Levels of Trace Elements $\mathrm{Cd}, \mathrm{Cu}, \mathrm{Pb}$ and $\mathrm{Zn}$ in Honey of Stingless Bee (Hymenoptera: Apidae) Using Voltammetry. Food and Nutrition Sciences 2015; 6: 591.

25. Sousa G. Composição E Qualidade De Méis De Abelhas (Apis Mellifera) E Méis De Abelhas Jataí (Tetragonisca Angustula): Thesis. Universidade de São Paulo. Brazil, 2008.

26. Denadai J, Ramos-Filho M, Costa D. Caracterização Físico-Química De Mel De Abelhas Jataí (Tetragonisca Angustula) Do Município De Campo Grande-Ms. Obtenção De Parâmetros Para Análise De Rotina. Anais XIV Cong Bras de Apicultura 2002: 80.

27. Iwama S. Coleta De Alimentos E Qualidade Do Mel De Tetragonisca Angustula Angustula Latreille (Apidae, Meliponinae). São Paulo 1977.

28. Suntiparapop K, Prapaipong P, Chantawannakul P. Chemical and Biological Properties of Honey from Thai Stingless Bee
(Tetragonula Leaviceps). Journal of Apicultural Research 2012; 51: 45-52.

29. de Almeida-Muradian LB. Tetragonisca Angustula Pot-Honey Compared to Apis Mellifera Honey from Brazil. Pot-Honey: Springer, 2013;375-82.

30. Almeida-Muradian LB, Stramm KM, Horita A, et al.,. Comparative Study of the Physicochemical and Palynological Characteristics of Honey from Melipona Subnitida and Apis Mellifera. International Journal of Food Science \& Technology 2013; 48: 1698-706.

31. Wanjai C, Sringarm K, Santasup C, et al.,. Physicochemical and Microbiological Properties of Longan, Bitter Bush, Sunflower and Litchi Honeys Produced by Apis Mellifera in Northern Thailand. Journal of Apicultural Research 2012; 51: 36-44.

32. Yadata D. Detection of the Electrical Conductivity and Acidity of Honey from Different Areas of Tepi. Food Science and Technology 2014; 2: 59-63.

33. Ramalhosa E, Gomes T, Paula Pereira A, et al.,. 4 Mead Production: Tradition Versus Modernity. Advances in food and nutrition research 2011; 63: 101.

34. Alvarez-Suarez JM, González-Paramás AM, Santos-Buelga $C$, et al.,. Antioxidant Characterization of Native Monofloral Cuban Honeys. Journal of agricultural and food chemistry 2010; 58: 9817-24.

35. Khalil M, Alam N, Moniruzzaman M, et al.,. Phenolic Acid Composition and Antioxidant Properties of Malaysian Honeys. Journal of food science 2011; 76: C921-C8.

36. Gomes S, Dias LG, Moreira LL, et al.,. Physicochemical, Microbiological and Antimicrobial Properties of Commercial Honeys from Portugal. Food and Chemical Toxicology 2010; 48: 544-8.

37. Spano N, Casula L, Panzanelli A, et al., . An Rp -Hplc Determination of 5Hydroxymethylfurfural in Honey: The Case of Strawberry Tree Honey. Talanta 2006; 68: 1390-5.

38. Fallico B, Arena E, Verzera A, et al.,. The European Food Legislation and Its Impact on Honey Sector. Accreditation and Quality Assurance 2006; 11: 49-54.

39. Vit $P$, Medina $M$, Eunice Enríquez M. Quality Standards for Medicinal Uses of Meliponinae Honey in Guatemala, Mexico and Venezuela. Bee World 2004; 85: 2-5. 